\title{
Ricoeur's Phenomenology of the Ego: A Clinical Emphasis
}

\section{Tim Davidson}

Ricoeur's phenomenology of the ego is important for contemporary thinkers and mental health practitioners to consider because of its implications for conceptualizing clinical experience and re-valuing the role of subjectivity within it. His approach emphasizes two parallel lines_-or discourses — for understanding clients: one which evaluates the objective data about them and another which appreciates their subjective accomplishments. Ricoeur defends the latter discourse about the "ego" at a time when the relevance of the concept of the ego has waned in the social and human sciences. By drawing from Husserl's notion of the ego, Freud's analysis of the unconscious, and the existentialists' descriptions of intentional lived experience, Ricoeur advances an understanding of the ego in which the ego, though decentered, remains a point of focus. Recognizing that "the notion of identity oscillates between presumption and demand,"1 Ricoeur tries to secure an understanding of human experience that is not "only scientific" but also accounts for the human dimension unfolding "from threshold to threshold through an increase in meaning." 3 The "ego" in Ricoeur's sense is thus hermeneutical as much as transcendental, unveiled (on "the edge of the unknown", to cite Blanchot) as much as a privileged center of meaning. ${ }^{4}$

The $20^{\text {th }}$ Century witnessed the rise, rule and fall of the ego in psychological theory. DNA, neurotransmitters, bio-chemistry and genetics have now become the dominant concepts. It is easy to see how the "subject's simple liquidation" is likely to follow from this 


\section{RICOEUR'S PHENOMENOLOGY OF THE EGO}

prevailing scientific view, but can the "neuronal assembly" - the "physical traces of how meaning is accessed" — give us any authentic sense of the individual, apart from its role in a reductionist biology? In clinical theorizing, for example, there is little interest in the ego, which has now become, in Borch-Jacobsen's words, an "infinitely decentered subject" (only the " $o$ " of "cogito" is preserved, and that, just barelyspecifically as the cogitatum). ${ }^{8}$ For clinicians, the more dominant ways to conceptualize human experience are now through observable behaviors and interactive systems. For this reason, you are likely to hear a psychologist say about his or her work: "I am a cognitive-behavioral therapist; I try to influence clients' maladaptive thoughts and modify their self-defeating patterns of behavior; but, no, I don't do analysis or ego psychology; I only think about the ego in a somewhat inconsequential sense, in reference to the client's general concept of self, or maybe I'll use the word 'ego' as an adjective, to describe egostrengths." What has brought this about?

Briefly stated, the demise of the ego occurred in the following way: (1) The psychoanalytic ego fell into its own black hole. In psychoanalysis, the ego was conceptualized as secondary rather than primary. Instead of being an irreducible center of experience, the ego was said to be derived from object relations with others, relations that were imposed on the infant in its dependency. As Freud puts it, "the ego is not master in its own house," and the "core of our being...is formed by the id, which has no direct relations with the external world..."10 (2) Over time, the bumanistic ego (generally conceptualized in the third person as a "self") degenerated into a nebulous theoretical construct. By and large, humanists skipped over Husserl and were bereft of any moorings for the ego. Wanting to bolster the ego in their clinical work, humanistic psychologists were thus left with softly-packaged appeals to encourage the ego-development of clients, but had no clear idea as to the nature of the ego. (3) The behaviorists could not see or measure an ego, and therefore, declared it irrelevant or non-existent. With no need for an ego, behaviorists moved in the direction of mechanistic models, mapping out certain responses they could stimulate in their clients and deciding what actions to reinforce in others. There was no need to postulate an ego, because only observable, external behaviors were relevant. (4) Systems theorists found it more useful to inquire into aggregate and interactive structures, like family, culture and environment. In systems work, the primary focus is on 


\section{TIM DAVIDSON}

communication patterns, adaptive rules and functional roles. The client's world is understood solely on the social level. While still retaining the concept of "individuation," the ego in systems theory functions simply as a plot on a graph. (5) The cognitive schools of psychology, harking all the way back to Epictetus and Descartes, revived interest in mental processes toward the end of the $20^{\text {th }}$ Century. In doing so, however, the notion of the ego was not their point of emphasis. Shying away from the "ghost in the machine," they described mental processes without any reference to the activities of a centralized ego. By now, the ego has been refuted, reduced, replaced by chemistry, derived from id impulses, constituted as secondary in scope, ignored, ridiculed essentially, pronounced dead. ${ }^{11}$

Even while accepting the Freudian suspicions about the ego, clinically, some of us think that Husserl was right to assert the importance of the ego, an "I (who am I)", constituting a world of experience, more basic and vital than any psychological constructs. Together, Freudian and Husserlian views on the ego reflect both the tentativeness and the absoluteness of subjectivity that constantly appears in clinical interviews. The client is clearly pre-cast within an environment, a particular psychological destiny and a biological lineage, while simultaneously creating, or shaping, a world on his or her own terms. What is needed, then, is a way to critically advance the insights of both Freud and Husserl. Without getting stuck in idealistic or empiricist theorizing, Ricoeur develops a conceptual link between Freud and Husserl. With Freud's topology, Ricoeur is able to save the baby (i.e. retain the entwined, layered unconscious and conscious dimensions of subjectivity), and with Husserl's phenomenology he is able to make the bathwater a little less murky (i.e. apply complicated philosophical theory to clinical praxis).

In building the bridge between psychoanalysis and phenomenology, Ricoeur recognizes that Freudian theory explores important psychological phenomena but ends up with an "indefinite self-symbolization" for the ego, with subjectivity viewed as "the series of its derivatives."12 Instead of portraying the ego either as a passive receptacle or a theoretical construct, however, Ricoeur follows Husserl's key insight that there is an "oriented constitution" of all phenomena. ${ }^{13}$ The ego is the center of orientation for all experiences a person might live through, including those "unconscious" states such as repressed memories, hidden desires, fears or instincts. As Husserl puts it, "anything 


\section{RICOEUR'S PHENOMENOLOGY OF THE EGO}

that is - whatever its meaning and to whatever region it belongs-is an index of a subjective system of correlations." ${ }^{\text {"14 }}$

With Freud's focus on the "semantics of desire" (accommodating the nuclear theme that, "as a man of desires I go forth in disguise-larvatus prodeo" $),{ }^{15}$ Ricoeur notes that psychoanalysis can get lost too easily "in the vicissitudes of instincts" if those drives are not grounded transcendentally. ${ }^{16}$ The Freudian unconscious is considered at its deepest levels to be pre-linguistic, as evidenced by images in regressive dreams or paleological thought processes in decompensated schizophrenic patients. In contrast, Husserl portrays the unconscious as an "inconspicuous stratum", ${ }_{17}$ "an abiding temporal being" consisting of "flowing changes in its typically modified manners of givenness within a living present" occasionally bearing "enduring results" linked to previous experiences "from then on and not merely during its living retention." ${ }^{18}$ A childhood sexual trauma, for example, may only be partially recollected in adult life but yet is constituted on various levels, sometimes as flashbacks, other times as affects, and still other times as panicked sensations. Noting this, Ricoeur holds that "every mode of appearing is correlative to a non-appearing or even a disappearing, both signified together, co-signified, in the presumption of the thing itself." ${ }^{\prime 9}$

Ricoeur uses the terms "infra" and "supra" to highlight the contrast between the unconscious in Freud and Husserl, respectively. ${ }^{20}$ Whereas Freudian thinking attempts to burrow into the forgotten, subterranean dimensions of existence, Husserlian thinking maintains an orientation toward the whole person in the living present. Accordingly, "transcendental subjectivity" for Ricoeur should be considered the "locus or the heart of the rules governing interpretation" of the unconscious. ${ }^{21}$ The raw, pre-linguistic unconscious can then be suspended as to its "immediate meaning, or rather that chaos of meaning, and the displacement of apparent meaning and its meaninglessness into the field of deciphering." 22 Ricoeur explains that psychoanalysis, as an "exegetical science," has a narrower path than phenomenology: to examine "the relationships of meaning between substitute objects and the primordial (and lost) instinctual objects" 23 from a person's past and then to discover "what takes precedence in the order of distortion or disguise" 24 in a particular person's life. The interpretive approach of psychoanalysis, advocated by Ricoeur, is intended to draw the hidden meaning of unconscious phenomena back to a constituting ego. So, while Freudian research into the 


\section{TIM DAVIDSON}

unconscious is an "epoche in reverse", a "reduction of consciousness", Husserl's epoche is a "reduction to consciousness." 25

For Ricoeur, like Husserl, the "psyche" is a "constituted region woven into the surrounding world of the pure ego." 26 Psychoanalytic theorists, in Ricoeur's view, are usually concerned "more with the ego's submission than with its striving" 27 and thereby tend to ignore the truth of subjectivity: the ego in its basic sense is not a thing to be battered by id impulses and conditioned by super ego constraints but "a living being, which from all time has, as the horizon of all its intentions, a world, the world." 28 For Ricoeur, following Husserl's teaching, the pure ego, then, should be understood as this "primal interiority", that "irreducible core." 29

Ricoeur, of course, pays close attention not only to Freud but also to the lessons of Heidegger, Sartre, and Merleau-Ponty in his understanding that the ego is, first of all, 'there' 'in-the world,' tied to its body. The ego, then, is understood to be realized through its bodily existence in the life-world, representing the primal structure from which meaning derives. At the same time, however, he insists that the ego is not just immersed in the world. There is an "architecture of meaning" in experience, that is, a "complicated intentional structure" consisting of "a relation of meaning to meaning, of second meaning to first meaning" even as "the first meaning disguises or reveals the second." 30

Ricoeur emphasizes that meanings are constantly established even when one goes unaware of them. In fact, acts of reflection often lag, or lurk, behind meanings. The ego, as a consciousness of a world which establishes the meaning of the world, is pervasive as life unfolds. Ricoeur writes: "Consciousness nourishes itself by re-centering itself around its Other: cosmos, bios, or psyche. It finds itself by losing itself. It finds itself instructed and clarified after losing itself and its narcissism." ${ }^{31}$ Whereas other views of the ego in psychology lose sight of intentionality, Ricoeur emphasizes its fundamental role in the ego's functions. All of the "architecture of meaning" in a person's life is constituted intentionally - even non-intentional, unconscious and hidden phenomena, which are initially cloaked, can be revealed in various types of intentionality through hermeneutic inquiry. Ricoeur makes it clear that Husserl's "absolute ego" is not some thing, out there in the world, to be dismantled while living... or to be preserved, inevitably, in dying. The ego is discovered only in these patterns of meaning-formation. An accurate image of the ego, for Ricoeur, thus leads us "not to a terminus but to a threshold." 32 


\section{RICOEUR'S PHENOMENOLOGY OF THE EGO}

While Ricoeur thinks of psychoanalysis as research back into "sedimented consciousness" or an archaeology of the ego, he follows the existential emphasis on the future orientation of being-in-the world as well. Ricoeur describes this as a teleology of the ego and even leaves open the possibility of an eschatology of the ego, trying to cast human consciousness as unfolding indefinitely from its finite embodiment toward infinity ${ }^{33}$ Ricoeur's portrayal of the ego, as open to an infinite horizon, highlights the living person's potentiality rather than his or her physically or socially-defined realities. The ego is provisional-with its questionable, hidden past and its uncertain future-but with the same brushstroke, necessary for the formation of meaning. The ego's search for meaning is the reason why, according to Ricoeur, "the human sciences may be said to be hermeneutical." 34

For clinicians, this emphasis on "meaning-formation" as a central way of understanding an ego immersed in the world is more useful than thinking of the ego either as a rational core fending off anxieties and disconnected from impulses or as some psychological construct that needs coddling in order to ensure its well-being. Meaning is entangled just as fully in the irrational, the bodily, the as-yet undisclosed, and the collective as it is in the reasonable, mentally managed, previously recognized and singular. With this hermeneutical approach to the ego, Ricoeur encourages philosophers and psychologists alike to understand human experience systematically, to "question back from uttered meaning to meaning in operation." ${ }^{35}$ The goal is to listen carefully to the communicated message, search for its meaning, and recognize the communicator's intentionality at some level of experience. "What we understand first in discourse," Ricoeur notes, "is not another person, but a project, that is, the outline of a new being-in-the world." ${ }^{36}$ For example, consider three utterances: the first from a politician, the second from a songwriter, and the third from a schizophrenic patient.

(1) The politician says, "We will be greeted as liberators"37 and we hear the utterance as understandable, a validity claim that needs to be verified; it may be wrong, culturally uniformed and arrogant, but it still seems clear, distinct, and marked by a coherence often associated with rationality. The hermeneutical effort rests on exploring the context for such a statement, acquiring more facts, gaining a perspective on media spin, and weighing the impact of public consensus regarding truthfulness. 


\section{TIM DAVIDSON}

(2) The artist sings, "I fought against the bottle, but I had to do it drunk. Took my diamond to the pawn shop, but that don't make it junk," ${ }^{38}$ and we immediately begin to decipher a meaning based on our past experiences; the language is playful, with double meanings; our imaginations are activated. The hermeneutical effort rests on an appreciation of poetic license and an understanding of addiction and nouveau poverty.

(3) The schizophrenic person writes in his journal, "product of held 2 screwplate on chair. Chromcraft Corporation St. Louis 20 Mo. ...Don't overlook perl's in swine. Don't swallow a nat and eat a whale. Science is a slave. Science is an emotion drive..." ${ }^{39}$ When he hands us his journal and we try to understand what this patient means, we do not know if he is uttering something intended to be understandable in a public arena at the time it was written, or if he is giving us anything more than a jumble of phrases. Maybe the act of sharing the journal is where the meaning lies, rather than the specific words. The hermeneutical effort rests on interpretation, empathic positioning, relationship development, medical analysis and knowledge of schizophrenic thought processes.

The politician comes across as purposeful and presumptive; the songwriter as poetic and humorous; and the patient as psychotic and un-medicated. From Ricoeur's perspective, though, all three communicators are constituting egos, laying out a field of meaning, within a temporal horizon, in a shared world. The politician is not just a mouthpiece; the songwriter is not just damaged goods; and the schizophrenic is not just a patient within a hospital system.

In clinical work, we regularly diagnose, consider demographics, and apply standardized assessments as part of the therapeutic enterprise. An ongoing challenge for clinicians is not to objectify the client too extensively and not to portray the client just as a profile, a grouping of symptoms. Of course, the client's mental status is a constant feature of the intersubjective moment, always 'there', awaiting the reflective turn of the clinician: the client's emotional states; overt behaviors; motor status; facial expressions; orientation to person, time and place; the process of presenting ideas; the content of that thought; or the capacity of memory, intellectual function and insight. Yet, all these ingredients- 


\section{RICOEUR'S PHENOMENOLOGY OF THE EGO}

the stuff of biology and psychology—do not add up to equal what Ricoeur highlights in the ego.

Ricoeur's phenomenological impulse is to approach the client holistically. No matter how elaborately the data of a person's life are scrutinized, organized and categorized, what is measured only gives the clinician a profile of the person. When someone speaks (or signifies non-verbally), professionalized discourse can readily cover over the "project" of another person and therein objectify (even eliminate) the constituting ego in favor of a third-person point of view. But Ricoeur points beyond such objectification to a hermeneutics of unveiling, where the constituting ego is immeasurable. In language, "a self announces itself before a world" 40 and, to use Buber's phrase, calls for an "IThou" meeting "where meaning is to be found... in this 'between' which they live together." ${ }^{41}$ Ricoeur's phenomenology emphasizes that human experience is fundamentally defined once we recognize and honor our own "presence" and the "co-presence" of others in the world. As constituting egos, we are thrown into existence. Once here, we are constantly tugged toward non-being, toward eradication of our identity and toward vanity rather than authenticity. Even so, Ricoeur urges us, in theory and in daily practice, to value subjectivity, neither ignoring the other as ego, nor disregarding our own "egological foundation."

Is this notion of the ego defensible? Will it be a useful way to describe the subject for clinicians hoping to maintain conceptual integrity in an era when spiritual, humanist and rationalist perspectives are consistently deconstructed and abandoned? Some might think of the pure ego, in Husserl's and Ricoeur's work, as a false image: an abstracted ghost in spiritual or theological terms, an unnecessary construct in psychological terms, or a pretense in existential terms. Ricoeur, however, lays claim to the ego as the basis for a genuine, individual sense of being. In so doing, Ricoeur reminds us that we are more than the sum of our mental and physical parts. This 'something more' is posed, not as a mere abstraction, but as a feature of concrete existing.

Ricoeur recognizes the concept of "spirit" as a valid way of thinking about this "something more." This term, for him, is "endowed with a polysemy that is very rich on the plane of subjective experience" whether used in the "general sense of the mental" (including "intentionality, meaning, communicability, and mutual understanding"...the terms emphasized in this discussion), or as an "inspired dimension" (a purified form of "integral experience"), or under the heading of the "transcendental" (as meant by medieval 


\section{TIM DAVIDSON}

philosophers to refer to "that which aims at the true, the good, the just, the beautiful"). ${ }^{43}$ All of these senses of the term "spirit" can benefit a clinical practice that strives for humanizing moments while still being rooted in scientific facts.

With this understanding of the ego, Ricoeur is also lending support to a moral argument that every person is of ultimate value. At one point, Ricoeur hints that "the vague term, the 'sacred',"44 could be applied to the ego. If Ricoeur's nod toward the ego as sacred is tenable as a phenomenological insight, it must include the provision that only by living in the mundane, profane, sensual world of other subjects will the sacred be realized. That is really the point for clinical work: recognition of the ego's "absoluteness" should not detract from the ego's brokenness or vulnerability as the ego "objectifies itself... as an element of the world." "45; conversely, the most mentally and emotionally disabled person should still be recognized to be "functioning ultimately" ${ }^{46}$ as a kindred spirit.

Social scientists and clinicians need — as much today as ever before- a way to conceptualize human experience rigorously but yet as uniquely personal and valuable. Paul Ricoeur's phenomenology of the ego lays out just such a theoretical foundation.

University of Oklahoma

\section{Notes}

${ }^{1}$ Jean-Pierre Changeux and Paul Ricoeur, What Makes Us Think?: $A$ Neuroscientist and Philosopher Argue about Ethics, Human Nature and the Brain (Princeton: Princeton University Press, 2000), 168.

${ }^{2}$ Changeux and Ricoeur, What Makes Us Think?, 175.

${ }^{3}$ Changeux and Ricoeur, What Makes Us Think?, 246.

${ }^{4}$ Maurice Blanchot, "Who?," in Who Comes after the Subject?, eds. E. Cadava, P. Connor and J. Nancy (New York: Routledge, 1991), 59.

${ }^{5}$ Jean-Luc Nancy, "Introduction," in Who Comes after the Subject?, eds. E. Cadava, P. Connor and J. Nancy, (New York: Routledge, 1991), 5.

${ }^{6}$ Changeux and Ricoeur, What Makes Us Think?, 96.

${ }^{7}$ Changeux and Ricoeur, What Makes Us Think?, 107.

${ }^{8}$ Mikkel Borch-Jacobsen, "The Freudian Subject, from Politics to Ethics," in Who Comes after the Subject?, eds. E. Cadava, P. Connor and J. Nancy (New York: Routledge, 1991), 63.

'Sigmund Freud, "One of the difficulties of psycho-analysis," 23 


\section{RICOEUR'S PHENOMENOLOGY OF THE EGO}

${ }^{10}$ Sigmund Freud, An Outline of Psycho-analysis trans James Strachey, (New York: WW Norton, 1989), 67.

${ }^{11}$ Post-modern schools tend to emphasize individual meaning, language and systems of interaction and conceptually are in sync with Ricoeur's phenomenology, although not typically emphasizing a hermeneutical or transcendental ego, and thinking more exclusively of the self as socially constructed.

${ }^{12}$ Paul Ricoeur, Husserl: An Analysis of his Phenomenology (Evanston: Northwestern University Press, 1967), 112.

${ }^{13}$ Edmund Husserl, Cartesian Meditations, (The Hague: Martinus Nijhoff, 1960), 134.

${ }^{14}$ Edmund Husserl, The Crisis of European Sciences and Transcendental Phenomenology [The Crisis] (Evanston: Northwestern University Press, 1970), 165.

${ }^{15}$ Ricoeur, Freud and Pbilosophy, 7.

${ }^{16}$ Ricoeur, Freud and Philosophy, 6.

${ }^{17}$ Edmund Husserl, Formal and Transcendental Logic (The Hague: Martinus Nijhoff, 1969), 318.

${ }^{18}$ Husserl, Formal and Transcendental Logic, 320.

${ }^{19}$ Ricoeur, Freud and Pbilosophy, 386.

${ }^{20}$ Ricoeur, Freud and Philosophy, 405.

${ }^{21}$ Ricoeur, Freud and Philosophy, 431.

${ }^{22}$ Ricoeur, Freud and Philosophy, 376.

${ }^{23}$ Ricoeur, "Existence and hermeneutics," 359.

${ }^{24}$ Ricoeur. "Existence and hermeneutics," 154.

${ }^{25}$ Ricoeur, Freud and Philosophy, 121.

${ }^{26}$ Ricoeur, Husserl: An Analysis, 52.

${ }^{27}$ Ricoeur, Freud and Philosophy, 185.

${ }^{28}$ Ricoeur, "Existence and hermeneutics," in Contemporary Hermeneutics: Hermeneutics as Method, Philosophy and Critique, ed. J. Bleicher (London: Routledge \& Kegan Paul, 1980), 241.

${ }^{29}$ Ricoeur, Freud and Philosophy, 448.

${ }^{30}$ Ricoeur, Freud and Philosophy, 18.

${ }^{31}$ Ricoeur, "Psychoanalysis and the Movement," 332.

${ }^{32}$ Ricoeur, Freud and Pbilosophy, 176.

${ }^{33}$ Ricoeur, "Existence and hermeneutics," 255.

${ }^{34}$ Paul Ricoeur, "The Model of the Text: Meaningful Action Considered as Text," in Interpretive Social Science: A Reader, eds. P. Rainbow and W. Sullivan (London: University of California Press, 1979), 76.

${ }^{35}$ Ricoeur, "The Model of the Text," 75.

${ }^{36}$ Ricoeur, "The Model of the Text," 79.

${ }^{37}$ T. Russert, "Interview with Vice-President Dick Cheney, Transcript" in NBC News' Meet the Press (New York and Washington, D.C.: National Broadcasting Company, Inc., March 16, 2003). 


\section{TIM DAVIDSON}

${ }^{38}$ L. Cohen, "That Don't Make It Junk," Ten New Songs [compact disc] (New York: Columbia Records, 2001).

${ }^{39}$ E. Sinnett, "The Diary of a Schizophrenic Man," in The Inner World of Mental Illness: A Series of First-Person Accounts of What It Was Like, ed. B. Kaplan (New York: Harper and Row Publishers, 1964) 189.

${ }^{40}$ Changeux and Ricoeur, What Makes Us Think?, 203.

${ }^{41}$ Martin Buber, "Elements of the Interhuman," Psychiatry 20 (1957): 106.

${ }^{42}$ Edmund Husserl, The Paris Lectures (The Hague: Martinus Nijhoff, 1970).

${ }^{43}$ Changeux and Ricoeur, What Makes Us Think?, 172-174.

${ }^{44}$ Ricoeur, Frend and Pbilosophy, 55.

${ }^{45}$ Husserl, The Crisis, 151-153.

${ }^{46}$ Husserl, Formal and Transcendental Logic, 256. 